EGU2020-11195, updated on 03 Dec 2021

https://doi.org/10.5194/egusphere-egu2020-11195

EGU General Assembly 2020

(c) Author(s) 2021. This work is distributed under

the Creative Commons Attribution 4.0 License.

\title{
From Pasture and Cropland to Nut Orchards: Modelling the Dynamics of Carbon Sequestration by Agroforestry Systems in the Temperate Climate Zone.
}

Erik Roest ${ }^{1}$, Angelique Lansu ${ }^{1}$, Ton Baltissen ${ }^{1,3}$, and Stefan C. Dekker ${ }^{1,2}$

'Open University of the Netherlands, Faculty of Science, Environmental Sciences, Heerlen, Netherlands (roesterik@gmail.com)

${ }^{2}$ Utrecht University, Copernicus Institute of Sustainable Development, Environmental Sciences, Utrecht, Netherlands

${ }^{3}$ Cropeye, www.cropeye.com, De Lier, Netherlands (ton.baltissen@cropeye.com)

Planting trees is suggested as a cheap measure to capture $\mathrm{CO}_{2}$, but might conflict with agricultural land use. Changing pasture and cropland into agroforestry systems like nut orchards might increase carbon (C) sequestration, without encroaching on agricultural land use. C-sequestration can act as a climate engineering measure to mitigate increasing $\mathrm{CO}_{2}$ emissions to the atmosphere. The general discourse is that agroforestry systems can sequester more carbon than cropland or pastures. Data on the impact of land use change from agriculture to agroforestry systems like nut orchards in the temperate climate zone are scarce.

In this study we analysed C-sequestration dynamics in above and below soil stocks and fluxes, from the perspective of global climate mitigation. Field measurements and lab results on chronosequences from pasture and cropland to stands of Corylus and Juglans trees have been combined with modelling future pathways at the level of parcels. The object of study was a temperate nut orchard located on sandy soils in the Netherlands (Province Gelderland).

Data on C stocks and fluxes have been collected in four methods: (1) field sampling analysed in a laboratory, (2) field survey, (3) collecting historic agricultural management data by interviewing and document analysis, and (4) analysing data by literature review. Focus was on C-stock data analysis and additional analysis of the C-budget change over years (chronosequence).

Results show different patterns (all data related to sequestration in reference plots):

C-sequestration in soil organic carbon (based on field samples, $0-60 \mathrm{~cm}$ depth) ranges from -0.1 to 2.2 Mg Cha $\mathrm{yr}^{-1}$.

C-sequestration in Corylus trees (based on field data and allometric equations) ranges from 0.5 to $1.2 \mathrm{MgCha} \mathrm{yr}^{-1}$.

C-sequestration in Juglans trees (based on field data and allometric equations) ranges from 0.3 to $0.7 \mathrm{MgC} \mathrm{ha}{ }^{-1} \mathrm{yr}^{-1}$. 
C-sequestration in below ground biomass (based on allometric equations) ranges from 0.06 to 0.4 Mg C ha ${ }^{-1} \mathrm{yr}^{-1}$.

The parameterized allometric equations show a large increase in C-sequestration, ranging from 0.9 to $3.5 \mathrm{Mg} \mathrm{ha}^{-1} \mathrm{yr}^{-1}$. Compared to grassland and cropland estimates this is 10 times higher, meaning a potential useful contribution to the mitigation of $\mathrm{CO}_{2}$ emissions. Further we observed an increase in quality of soil organic carbon, due to a shift to higher C/OM and C/N levels, lower annual OM breakdown and larger amounts of observed earthworms. 